\title{
MANAJEMEN PUBLIC RELATIONS SEBAGAI ALAT ETIKA KOMUNIKASI DALAM BISNIS ISLAM ${ }^{*}$
}

\author{
Yuke Rahmawati ${ }^{1}$ \\ Permalink: https://www.academia.edu/9991531
}

\begin{abstract}
Public Relations Management as a Tool of Business Communication Ethics Islam. Public relations is as an intermediary between the head of the organization and its publics. In an effort to foster good community relations, internal and external. Public relations profession generally believed to be a facilitator, motivator, and even become agents of change. One definition says PR is a method of communication to create a positive image of the partner organization on the basis of respecting mutual interests. Management of public relations in the business of Islam, does not give a different sense, because basically the concept of PR is highly recommended in Islam. If the analogy meaning of public relations as a procedure for communicating the good, true and effective, then the concept of Islam has clearly explain to some verses in the Koran.
\end{abstract}

Keywords: Public Relations, Islamic Business, Management, Methods

\begin{abstract}
Abstrak: Manajemen Public Relations Sebagai Alat Etika Komunikasi Dalam Bisnis Islam. Public relations merupakan sebagai perantara antara pimpinan organisasi dengan publiknya. Baik dalam upaya membina hubungan masyarakat internal, maupun eksternal. Profesi public relations pada umumnya diyakini akan menjadi fasilitator, motivator, bahkan menjadi agen perubahan. Salah satu definisi menyebutkan PR adalah metode komunikasi untuk menciptakan citra positif dari mitra organisasi atas dasar menghormati kepentingan bersama. Manajemen public relations pada bisnis Islam, tidak memberikan pengertian yang berbeda, karena pada dasarnya konsep PR ini sangat direkomendasikan dalam Islam. Bila dianalogikan makna public relation sebagai tata cara berkomunikasi yang baik, benar dan efektif, maka konsep Islam telah jelas menerangkannya pada beberapa ayat dalam Alquran.
\end{abstract}

Kata Kunci: public relation, bisnis Islam, manajemen, metode

* Diterima tanggal naskah diterima: 02 Juli 2014, direvisi: 26 Agustus 2014, disetujui untuk terbit: 15 November 2014.

${ }^{1}$ Fakultas Syariah dan Hukum UIN Jakarta. Jl. Ir. H. Juanda No. 95 Ciputat Jakarta. E-mail: uke rahmawati@yahoo.com 


\section{Pendahuluan}

Mengembangkan pola bisnis/usaha merupakan salah satu yang dianjurkan dalam Islam. Perintah Allah terkait dengan mencari berbagai kegiatan bisnis/usaha ini banyak diutarakan dalam al-Quran. Al-Quran sebagai pegangan hidup telah mengatur kegiatan bisnis secara eksplisit dan memandang bisnis sebagai sebuah pekerjaan yang menguntungkan dan menyenangkan, sehingga al-Quran sangat mendorong dan memotivasi umat Islam untuk melakukan transaksi bisnis dalam kehidupan mereka.

Legitimasi bisnis ini dipaparkan dalam bentuk prinsip-prinsip, yakni kebebasan dalam usaha, keadilan sosial dan tatakrama perilaku bisnis. Kebebasan dalam usaha dimaksudkan bahwa manusia muslim wajib melaksanakan secara penuh semua aturan bisnis yang ditata oleh al-Quran. Sementara, prinsip keadilan sosial lebih pada anjuran supaya semua pelaku bisnis muslim harus melakukan segala upaya membangun kepercayaan mitranya, peduli terhadap hukum perlindungan hak-hak dan kewajiban antar kedua pihak serta menjauhi transaksi yang bersifat eksploitatif. Sedangkan prinsip tatakrama perilaku bisnis mengarahkan, bukan saja pada aspek keadilan, tetapi juga pada pola pengelolaan terstruktur dimana bisnis tersebut dijalankan. Pertanggungjawaban secara individu dalam berbisnis sesungguhnya menjadi pakem dalam al-Quran, bahwa setiap individu tidak punya previlage dan imunitas dalam menghadapi konsekuensi pada apa yang dilakukan.

Prinsip tatakrama perilaku bisnis merupakan unsur yang terkait dengan beberapa hal, diantaranya terkait etika dalam berbisnis dan komunikasi dalam bisnis. Kedua hal tersebut tentunya memiliki pengaruh kuat terhadap berkembangnya suatu kegiatan bisnis. Etika dalam bisnis lebih menekankan pada aspek moral yang benar dan salah. Penerapannya berupa standar moral dalam kebijakan, institusi dan perilaku bisnis. Sementara komunikasi bisnis secara umum memiliki tujuan memberi informasi (informing), melakukan persuasi (persuasing), dan melakukan kolaborasi (collaborating) dengan audiens.

Penulis secara spesifik mengarahkan tulisan ini pada pola pengelolaan komunikasi dalam bisnis, pada bagaimana secara menejerial seorang pelaku bisnis bisa memanage konsep public relation--sebagai salah satu pola komunikasi-- dalam bisnis Islam.

\section{Definisi Manajemen Public Relations}

Manajemen public relations merupakan penerapan fungsi-fungsi dasar manajemen dalam kegiatan public relations. Prakitisi public relations akan sangat membutuhkan fungsi-fungsi tersebut dalam membuat suatu konsep dan mengimplikasinya yang berkaitan dengan tugasnya. Dengan demikian mengelola public relations berarti melakukan penelitian, perencanaan, pelaksanaan dan evaluasi terhadap kegiatan komunikasi yang disponsori oleh organisasi. Manajemen ini merupakan terapan dari ilmu manajemen dasar yang diimplikasikan di dunia public relations. 
Manajemen merupakan suatu proses yang meliputi hal-hal sebagai berikut; $^{2}$ 1). Perencanaan (Planning) yang berisi; Penetapan tujuan standar, penentuan aturan dan prosedur, pembuatan rencana serta ramalan (prediksi) apa yang akan terjadi. 2). Pengorganisasian (organization) yakni Pemberian tugas terpisah kepada masing-masing pihak, membentuk bagian, mendelegasikan dan menetapkan sistem komunikasi, serta mengkoordinir kerja setiap karyawan dalam satu tim yang solid dan terorganisir. 3). Penyusunan Formasi (saffing) yakni, Menentukan persyaratan personel yang akan dipekerjakan, merekrut calon karyawan, menentukan pembagian tugas (job description) dan persyaratan teknis suatu pekerjaan, melakukan penilaian dan pelatihan termasuk di dalamnya pengembangan kualitas dan kuantitas karyawan sebagai acuan untuk penyusunan setiap fungsi dalam manajemen organisasi. 4). Memimpin (leading) yaitu membuat orang lain melaksanakan tugasnya, mendorong dan memotivasi bawahan, serta menciptakan iklim atau suasana pekerjaan yang kondusif, khususnya dalam metode komunikasi dari atas ke bawah atau sebaliknya, sehingga timbul saling pengertian dan kepercayaan yang baik serta menumbuhkembangkan disiplin kerja dan sense of belonging (rasa memiliki) pada setiap karyawan dan jajaran manajemen (public internal). 5). Pengawasan (controlling), yakni Fungsi terakhir manajemen ini mencakup; persiapan suatu standar kualitas dan kuantitas hasil kerja, baik berbentuk produk maupun jasa yang diberikan perusahaan/organisasi dalam upaya pencapaian tujuan, produktivitas dan terciptanya citra yang positif.

Public Relations juga disebut Hubungan Masyarakat, menurut Prof Edward L.B mempunyai tiga pengertian: 1. Memberikan penerangan kepada masyarakat, 2. Mendorong langsung terhadap masyarakat untuk mengubah sikap dan tindakan serta, 3. Usaha-usaha pengintegrasian sikap dan tindakan dari perusahaan dengan masyarakat dan dari masyarakat dengan perusahaan. Prof Byron C, mengatakan bahwa hubungan masyarakat adalah suatu usaha yang sadar untuk mempengaruhi orang terutama melalui komunikasi, guna berpikir baik terhadap organisasi, menghargai dan mendukungnya dan bersimpati dalam menghadapi tantangan dan hambatan. ${ }^{3}$ Komunikasi biasa diartikan sebagai transfer informasi atau pesan dari komunikator kepada komunikan yang bertujuan mencapai saling pengertian (mutual understanding). ${ }^{4}$

Penggunaan PR yang terencana pada sektor publik misalnya, mungkin akan terdapat banyak hambatan yang akan dihadapi oleh para manajer PR dibanding dengan yang berada di dunia komersial. Permintaan jasa-jasa PR oleh sektor-sektor sosial atau sukarela juga beragam. Bekerja untuk badan amal dapat sangat menyenangkan dan informal, sementara sebuah badan sosial yang

\footnotetext{
Andini Marta, Manajemen dan Public Relations, dalam http://strategikomunikasi.blogspot.com/2012/02/manajemen-dan-public-relations.html, diunduh pada tanggal 6 feb 2013.

${ }^{3}$ S.K. Bonar, Hubungan Masyarakat Modern, (Jakarta : penerbit Rineka Cipta, 1993), Cetakan -3 , hal. 12

${ }_{4}^{4}$ Redi Panuju, Komunikasi Bisnis, (Jakarta, PT. Gramedia Pustaka Utama, 2000), Cet-ke 2, hal. 4 .
} 
profesional mungkin akan lebih baku. Sehingga metode keputusannya bisa jadi sangat berbeda dan tentu saja kebutuhan jasa PR nya akan berlainan. Selain itu juga, untuk menciptakan pandangan yang positif di kalangan masyarakat sekaligus mempertahankannya. ${ }^{6}$

Yang paling utama dalam manajemen public relations ini adalah bagaimana proses pengorganisasian suatu organisasi atau perusahaan dalam mengkomunikasikan hasil produk barang dan layanan jasa sebagai keluaran (outputs) organisasi atau perusahaan tersebut dapat memberikan pengembalian (feedback) yang positif, baik kompensasi maupun kepuasan.

\section{Memolakan Fungsi dan Tugas dalam Proses $P R$}

Profesi public relations berperan sentral sebagai agen perubahan, bukan hanya disebabkan faktor kebijakan perusahaan yang menempatkan posisinya yang kurang strategis dalam manajemen, namun juga disebabkan beberapa faktor yang ada dalam diri/personal public relations tersebut. Antara lain personal di bidang profesi public relations harus memiliki: wawasan yang luas di bidang manajemen; pertimbangan yang matang untuk dapat mengambil keputusan secara matang; memahami dunia bisnis secara utuh; menguasai lingkungan sosial politik; dan memahami para stakeholder. Hal ini disebabkan beberapa masalah manajemen tidak hanya membutuhkan strategi komunikasi, melainkan membutuhkan perubahan manajemen yang lebih komprehensif. ${ }^{7}$

Menggerakkan dan menghidupkan setiap orang di semua tingkatan organisasi ke arah penciptaan value, akan mengurangi bahkan mengikis persaingan antar bagian yang diakibatkan oleh pluralitas tujuan yang ingin dicapai, atau akibat adanya ego sektoral. Faktor-faktor yang memiliki dampak pada proses penciptaan dan perusakan value adalah value driver. Value driver mencakup dua bentuk, yaitu value level dan value risk.

Value level adalah value driver yang dapat dikontrol secara langsung oleh perusahaan/lembaga. Karena dapat dikontrol, perusahaan bisa mengelola dan mengarahkan value driver sesuai misi dan tujuan yang ingin dicapai. Misalnya: karyawan, kompensasi, kepuasan pelanggan, dll. Sedang Value risk adalah value driver yang tidak dapat secara langsung dikontrol oleh perusahaan/lembaga, misalnya iklim bisnis dan regulasi pemerintah.

Sementara prinsip dasar profesi public relations adalah membangun kemitraan atau relationship secara internal dan eksternal, berdasarkan nilai-nilai utama yang menjadi falsafah atau pedoman moral perusahaan/organisasi. Nilai spiritual adalah nilai-nilai moral utama yang menjadi dasar pijakan atau falsafah perusahaan/lembaga yang bersumber dari keyakinan, kepercayaan, agama,

\footnotetext{
${ }^{5}$ Mike Beard, Manajemen Departemen Public Relations, (Jakarta: Penerbit Erlangga, 2001), Edisi Kedua, hal. 4

${ }_{7}^{6}$ Ibid, hal. 91

Ani Yuningsih, Peran Sstrategis Profesi Public Relation Dalam Membangun Kemintraan Berbasis Nilai Spiritual; Studi Deskriptif Analitis terhadap Peran Strategis Profesi PublicRelations Sebagai Fasilitator Kemitraan Antara Pemerintah, Komunitas Sipil dan Komunitas Bisnis dalam Meningkatkan Indeks Pembangunan Manusia (IPM) di Jawa Barat, Jurnal Mimbar, Volume XXII No. 4 Oktober - Desember 2006 : 496 - 520
} 
maupun budaya, sehingga secara psikologis menjadi "ruh" atau motor penggerak utama setiap aktifitas manusia dalam manajemen korporasi tersebut.

Setiap perusahaan/lembaga harus memahami, menentukan, dan mengarahkan penciptaan nilai moral spiritual ini, sehingga implementasi CSR tidak lagi sekedar menjadi tuntutan internal dan eksternal lembaga/perusahaan, tetapi sudah menjadi panggilan jiwa dari setiap anggota lembaga perusahaan. ${ }^{8}$

Mengenai fungsi dan tugas PR diantaranya adalah ${ }^{9}$ : (sebagian kutipan)

\begin{tabular}{|c|c|c|}
\hline No & Fungsi & Tugas/Kegiatan \\
\hline a. & $\begin{array}{l}\text { (Membantu) menentukan } \\
\text { dan merumuskan tempat } \\
\text { serta tujuan organisasi dalam } \\
\text { kehidupan bersama }\end{array}$ & $\begin{array}{l}\text { - Membantu merumuskan kebijakan } \\
\text { - Menilai organisasi dari segi } \\
\text { kemasyarakatan, budaya, dan ilmu } \\
\text { pengetahuan. } \\
\text { - Mengantisipasi berbagai reaksi }\end{array}$ \\
\hline b. & $\begin{array}{l}\text { PR memberikan masukan } \\
\text { bagi kebijakan dan langkah- } \\
\text { langkah selanjutnya }\end{array}$ & $\begin{array}{l}\text { - Mempelajari opini dan } \\
\text { interpretasinya } \\
\text { - Memberi advis untuk rencana } \\
\text { jangka pendek dan rencana jangka } \\
\text { panjang }\end{array}$ \\
\hline c. & $\begin{array}{l}\text { Memberi advis } \\
\text { kepemimpinan }\end{array}$ & $\begin{array}{l}\text { - Memberi penilaian mengenai } \\
\text { pembagian tugas dan anggaran } \\
\text { - Memberi bimbingan kepada yang } \\
\text { bekerja sama dengan pimpinan } \\
\text { - Memberikan saran bagi perbaikan } \\
\text { intern }^{10}\end{array}$ \\
\hline
\end{tabular}

Adapun pola pada proses public relations menurut Cultip Center akan melalui tahap: (a). Penemuan fakta (fact finding), (b) perencanaan (planning), (c) komunikasi (communicating), (d) evaluasi (evaluating). ${ }^{11}$ Aspek penemuan fakta diidentikkan dengan riset (penelitian), sedang prosesnya digambarkan sebagai berikut :

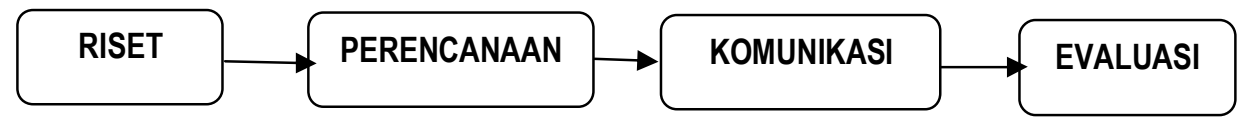

Yang dilakukan pada aspek riset ialah melakukan pemberitaan di media massa, melakukan pemberitaan yang berhubungan dengan institusi, menganalisis surat masuk, menganalisis catatan-catatan penjualan, menganalisis

${ }_{9}^{8}$ Ibid.

Andini Marta, Manajemen dan Public Relations, dalam http://strategikomunikasi.blogspot.com/2012/02/manajemen-dan-public-relations.html, diunduh pada tanggal 6 feb 2013.

${ }^{11}$ F. Rachmad, Public Relations dalam Teori dan Praktek, (Jakarta, Pt. Gramedia Pustaka Utama, 1993, hal 111. Lihat juga Redi Panuju, Komunikasi Bisnis, (Jakarta, PT. Gramedia Pustaka Utama, 2000), Cet-ke 2, hal. 95 
hasil pembicaraan para pemuka pendapat, mencari informasi melalui kontak personal dan membaca hasil polling dan hasil survei.

Pada aspek perencanaan yang baik hal yang harus diikuti adalah; mengumpulkan informasi, menganalisis informasi, mengidentifikasi problem, mencari sebab-sebab pokok, mengidentifikasi alternatif, memperhitungkan kekuatan, menyesuaikan rencana-rencana, memonitor aktivitas dan menyeleksi metode monitoring. Sementara komunikasi, merupakan proses terus menerus untuk menghubungan tujuan-tujuan dengan lingkungan internal (internal public), seperti pemberi keputusan, supervisi dan pekerja, maupun eksternal (external public), seperti pelanggan, pemasok dan publik. Sedangkan Evaluasi adalah menjawab pertanyaan berikut; apakah output sesuai tujuan, bagaimana supaya lebih baik di waktu yang akan datang, dan apakah hasil sesuai dengan perencanaan.

Dalam wilayah komunikasi, semua organisasi harus melakukan komunikasi dengan berbagai pihak dalam mencapai tujuannya tentunya dengan pendekatan bervariasi dan berbeda-beda. Dalam hal ini terdapat pola komunikasi yang bisa dilakukan, yakni bentuk komunikasi dari atas ke bawah (top down/downword communication), dari bawah ke atas (bottom-up/upword communication), horizontal (horizontal communications), dan komunikasi diagonal (diagonal communication). Adapun aspek evaluasi lebih menekankan pada keseluruhan kaitan aspek riset, perencanaan manajemen dan komunikasi dalam perusahaan /organisasi tersebut dengan melacak pada aspek manakah hambatan terjadi, sehingga proses public relations akan senantiasa termonitor dengan baik.

Pola ini sangat terkait erat dengan peranan public relations dalam sebuah organisasi yang berkaitan dengan tujuan utama dan fungsi-fungsi manajemen perusahaan. Fungsi dasar manajemen itu juga berkaitan dengan memanfaatkan berbagai potensi sumber daya manusia yang dimiliki oleh organisasi/perusahaan. Unsur-unsur sumber daya tersebut dinamakan 6-M, yaitu; sumber daya manusia (men), sumber material/barang yang dikuasai (material), alat atau perkakas mesin produksi (machine), kemampuan keuangan (money), metode yang dipergunakan (method), perluasan/pemasaran yang hendak dituju (market). Berhasil dan tidaknya fungsi-fungsi manajemen yang ada di perusahaan sangat tergantung pada seberapa besar pemanfaatan sumber daya 6-M tadi. Public relations merupakan sebagai perantara antara pimpinan organisasi dengan publiknya. Baik dalam upaya pembinaan hubungan masyarakat internal, maupun eksternal. ${ }^{12}$

Perkoordinasian seluruh unsur sumber daya tersebut akan melalui konsekuensi: a). kemampuan sebagai manajemen teknis (technical management), dan b). kemampuan sebagai manajer profesional yang ahli (manajerial skill). Kegiatan utamanya dalam mewakili top manajemen suatu lembaga atau organisasi tersebut merupakan kegiatan two ways

12 Irmulan Sati, Manajemen Public Relations, dalam http://kk.mercubuana.ac.id/files/99006-3-549085894829.doc, di unduh pada tanggal 8 februari 2013. 
communications yang merupakan pula ciri khas peranan public relations. Karena salah satu tugas PR adalah menjadi narasumber informasi (source of information) dan saluran informasi (channel of information). ${ }^{13}$

Profesi public relations pada umumnya diyakini akan menjadi fasilitator, motivator, bahkan menjadi agen perubahan. Peran fasilitator yang dimaksud disini adalah sebagai penggagas sekaligus pelaku implementasi berbagai program perusahaan/ lembaga. Misalnya program tanggung jawab sosial perusahaan, meliputi lapisan masyarakat yang benar-benar membutuhkan fasilitator dalam berbagai upaya meningkatkan kesejahteraan sosialnya. Seperti kalangan pedagang kecil, nelayan, petani, buruh, dan akhir-akhir ini para korban bencana alam, dan lain sebagainya. Berperan sebagai mediator, dalam hal ini humas juga berfungsi menjembatani hubungan antara para pengelola perusahaan dengan pemerintah dan berbagai elemen masyarakat lainnya. Sedangkan sebagai komunikator, humas senantiasa membangun persamaan persepsi dan makna atas berbagai kebutuhan masyarakat disatu sisi dan kepentingan perusahaan/lembaga di sisi lainnya, sehingga terjalin sinergi yang efektif yang pada akhirnya akan meningkatkan kesejahteraan bersama. Tidak dapat dipungkiri bahwa peran public relations saat ini dianggap sebagai ujung tombak bagi perusahaan yang berhadapan langsung dengan publik, baik itu publik yang bersentuhan langsung maupun yang tidak dengan kepentingan perusahaan seperti pihak pemegang saham. Contoh penerapannya, public relations membuka peluang akses informasi melalui media massa untuk memberikan gambaran mengenai aktifitas public relations, mengembangkan dan mengelola manajemen isu dengan baik sebagai bagian dari kekuatan perusahaan, misalnya: liputan mengenai profil dan kinerja perusahaan melalui media akan memberikan pencitraan yang baik bagi perusahaan dan pada akhirnya mampu menumbuhkan minat pemodal untuk menginvestasikan dana pada perusahaan tersebut.

\section{Kegiatan Public Relations dalam Bisnis}

Terdapat beberapa bidang kegiatan PR yang terangkum dalam perencanaan manajemen. Diantara kegiatan tersebut adalah: ${ }^{14}$

Pertama, Komunikasi Finansial. Salah satu tujuan pokok dari program ini ialah untuk menghindari peristiwa pengalihan paksa perusahaan, memasilitasi akuisisi, kemampuan memperoleh pinjaman atau kredit, dan mengarahkan komunitas keuangan perusahaan pada opini yang baik bagi perusahaan. Dimana tim PR dapat mengomunikasikan informasi-informasi tertentu pada Pemegang Saham (institusional, perorangan, potensial), Manajemen perusahaan (Ketua, eksukutif kepala, Direktur keuangan, Sekretaris Perusahaan), Penasihat Perusahaan (Pialang saham, Bank komersial, Auditor, Kunsultan Keuangan) dan Pihak Luar yang Berpengaruh (Analis Pialang Saham, Jurnalis keuangan, Analis peringkat Utang).
${ }^{13}$ Ibid.
${ }^{14}$ Redi Panuju, Komunikasi Bisnis, (Jakarta, PT. Gramedia Pustaka Utama, 2000), Cet-ke 2, hal. 15-19. 
Kedua, Hubungan dengan Pemerintah. Tujuan kegiatan ini adalah untuk meyakinkan bahwa pemerintah dan badan-badan publik lain peduli dengan perusahan bersangkutan dan memperhitungkan kepentingan sahnya berkenaan dengan kebijakan publik, peraturan dan perundang-undangan.

Ketiga, Komunikasi Pemasaran. PR dapat membantu menyediakan lingkungan reputasi yang tepat sehingga memungkinkan kaum profesional pemasaran dapat berperan secara lebih baik. Jalur komunikasi Pemasaran dengan tim PR ialah dengan Pelanggan (manajemen pelanggan, pemesan, distributor, bandar), Pihak eksternal (biro iklan, konsultan PR, konsultas desain, promosi), Manajemen Perusahaan, dan Pihak luar yang Berpengaruh (badan industri, wartawan, konsumen).

Keempat, Komunikasi Internal. Tujuan utamanya adalah memfasilitasi proses perekrutan dan memelihara pekerja berkualitas-tinggi yang mampu memberikan kontribusi positif terhadap kegiatan organisasi.

Kelima, Hubungan dengan Masyarakat. Tujuan hubungan dengan masyarakat ini adalah sebagai pencapaian atas pemahaman yang baik dan reputasi positif dengan masyarakat umum yang memiliki kepentingan dalam organisasi.

\section{Etika Dalam Profesi Public Relations}

Citra adalah suatu istilah baru yang menarik serta menjadi perbincangan masyarakat saat ini, bahkan menjadi topik internasional. Didalamnya terkandung prinsip kepentingan bersama (mutual interest) yang merupakan esensi dan kegiatan PR. Mempunyai cara kerja yang jelas dan menggunakan dua pihak (two way communications). Sebenarnya terdapat 5 persyaratan mendasar bagi profesi PR, yakni: 1) ability to communicate (kemampuan berkomunikasi ), 2) ability to organize (kemampuan manajerial atau kepemimpinan ), 3) ability on get the with people (kemampuan bergaul atau membina relasi), 4) personality integrity (memiliki kepribadian yang utuh dan jujur), 5) imagination (banyak ide dan kreatif). ${ }^{15}$

Kemampuan berkomunikasi bagi seorang PR dalam bentuk lisan maupun tulisan, yakni ia harus mampu berbicara di depan umum, harus mampu melakukan presentasi, mampu mewawancarai dalam upaya mengumpulkan fakta dan data, dan diwawancarai pers atau wartawan sebagai sumber berita dan kemampuan berkomunikasi lisan lainnya. Dalam komunikasi tulisan harus mampu membuat press release untuk dikirim ke media massa, membuat artikel dan feature untuk house journal yang akan diterbitkan perusahaan, menulis laporan, membuat naskah pidato untuk manajemen, menulis konsep iklan layanan masyarakat, menulis brosur dan selebaran dan bentuk komunikasi tulisan lainnnya.

Kemampuan manajerial dalam Personal Aproaching (pendekatan personal) harus dilakukan seorang profesi PR, kendati tetap dalam koridor

15 Admin, Tantangan dan Kompetensi Profesi Public Relations, dalam http://operadewa.wordpress.com/2011/12/11/tantangan-dan-kompetensi-profesi-publicrelations/, di undunh pada tanggal 18 Februari 2013 
mempertahankan integritas profesi masing-masing. Dalam melakukan kegiatannya PR selalu menerapkan etika profesi PR yang berlaku. Sehingga tidak menimbulkan salah informasi, salah komunikasi atau salah pengertian. Hubungan yang terjadi pada publiknya tercapai mutual understanding (saling pengertian).

Salah satu tugas praktisi public relations adalah mempertahankan citra baik lembaga/perusahaan di mata masyarakat/publik. Agar dapat mempertahankan citra perusahaan/organisasi seorang praktisi public relations harus giat melakukan penelitian-penelitian berkaitan dengan public relations. Dalam sebuah penelitian public relations terdapat metode analisis citra (image analysis). Menurut Philip Kotler, secara garis besar citra adalah seperangkat keyakinan, ide, dan kesan seseorang terhadap suatu obyek tertentu. Beberapa model pengukurannya yaitu: 1). Model Grid Analysis Citra (tanggapan khalayak), 2). Analisis Model Skala Pengenalan (familiarity scale), 3). Model Kenal Suka (favorability scale)

Kode Etik ini telah terdaftar sejak tahun 1977 di Departemen Dalam Negri dan Deppen saat itu, dan telah tercatat serta diakui oleh organisasi profesi Humas Internasional; International Public Relations Associations/IPRA. Didalamnya terkandung; 1). Dijiwai oleh Pancasila maupun Undang-Undang Dasar 1945 sebagai landasan tata kehidupan nasional, 2). Diilhami oleh Piagam Perserikatan Bangsa-Bangsa sebagai landasan tata kehidupan internasional, 3). Dilandasi Deklarasi ASEAN (8 Agustus 1967) sebagai pemersatu bangsa-bangsa Asia Tenggara, 4). Dan dipedomani oleh cita-cita, keinginan, dan tekad untuk mengamalkan sikap dan perilaku kehumasan secara professional.

Kode etik praktisi humas meliputi: 1). Code of conduct, yakni etika perilaku sehari-hari terhadap integritas pribadi, klien dan majikan, media dan umum, serta perilaku terhadap rekan seprofesi. 2). Code of profession, yakni etika dalam melaksanakan tugas/profesi humas. 3). Code of publication, yakni etika dalam kegiatan proses dan teknis publikasi. 4). Code of enterprise, yakni menyangkut aspek peraturan pemerintah seperti hukum perizinan dan usaha, hak cipta, merk, dll.

Aktivitas komunikasi publik, pada dasarnya berkaitan dengan tindakan sosialisasi dan pendidikan terhadap publik. Komunikasi publik, tidak hanya berlaku untuk publik luar melainkan juga untuk publik internal. Karena jika diantara publik internal tidak ada relasi yang harmonis, maka dampaknya buruk bagi citra organisasi. Kondisi demikian akhirnya justru menjadi pesan negatif dan melahirkan citra negatif organisasi di mata publik.

Pada konteks ini, maka public relations harus bisa membentuk nilainilai, pemahaman, sikap-sikap, sampai perilaku dari publik agar sejalan dengan kebutuhan organisasi. Melalui pengemasan pesan-pesan komunikasi publik yang lebih banyak berisikan tentang apa dan siapa serta apa manfaat keberadaan organisasi. Pesan-pesan ini dapat dikomunikasikan melalui media massa atau media lain yang dipilih sesuai dengan target sasaran (Suprawoto, 2006). Di sisi lain, sejalan dengan situasi faktual saat ini, kewajiban lembaga pemerintah khususnya para praktisi public relations adalah mendukung penyebaran dan pemerataan informasi publik ke seluruh lapisan masyarakat. 
Praktisi public relations atau petugas humas dapat mengarahkan unsurunsur potensial agar dapat membentuk opini publik sesuai dengan citra yang diinginkan oleh organisasi. Bagaimanapun juga kita mahfum, bahwa opini publik dan citra organisasi tentu saja merupakan faktor penting yang menentukan sukses atau gagalnya aktivitas dan pelaksanaan program organisasi.

\section{Public Relations dalam Bisnis Islam}

Public Relations dalam Islam dapat dikatakan sebagai dakwah pengenalan Islam. Dakwah ini berfungsi sebagai pengenalan Islam kepada masyarakat. Seorang pendakwah atau orang yang mensosialisaikan Islam pada masyarakat yang paling sukses adalah Nabi Muhammad saw. Rasulullah Saw. mengajak manusia ke jalan Allah dengan lemah lembut dan kasih sayang, sesuai dengan Firman Allah yang isinya: "Serulah (manusia) ke jalan Tuhanmu dengan hikmah (kebijaksanaan) dan pelajaran yang baik dan bantahlah mereka dengan cara yang lebih baik. Sesungguhnya Tuhanmu Dialah yang lebih mengetahui tentang siapa yang tersesat dijalan-Nya dan Dialah yang lebih mengetahui orang-orang yang mendapat petunjuk". (An-Nahl:125)

Lebih spesifik manajemen public relations pada bisnis Islam, tidak memberikan pengertian yang berbeda, karena pada dasarnya konsep PR ini sangat direkomendasikan dalam Islam. Bila dianalogikan makna public relation sebagai tata cara berkomunikasi yang baik, benar dan efektif, maka konsep Islam telah jelas menerangkannya pada beberapa ayat dalam al-Quran. Diantaranya: (70). Hai orang-orang yang beriman, bertakwalah kamu kepada Allah dan Katakanlah Perkataan yang benar,(71). Niscaya Allah memperbaiki bagimu amalan-amalanmu dan mengampuni bagimu dosa-dosamu. dan Barangsiapa mentaati Allah dan Rasul-Nya, Maka Sesungguhnya ia telah mendapat kemenangan yang besar.

Ayat diatas dimaknai bahwa dalam hal menyampaikan berbagai informasi haruslah benar dan dengan komunikasi yang baik. (28). Dan jika kamu berpaling dari mereka untuk memperoleh rahmat dari Tuhanmu yang kamu harapkan, Maka katakanlah kepada mereka ucapan yang pantas.

Ayat ini memberi pengertian bahwa dalam kewajiban saling memperhatikan diantara manusia satu dengan yang lain, bila masih terhalang untuk merealisasikannya (bershadaqah), maka berkomunikasilah atau berbicara kepada mereka harus tetap baik dan mengucapkan kalimat-kalimat yang pantas/layak. Dalam hal bisnis, maka baik perusahaan ataupun pelanggan bila mengahadapi suatu ketidaknyamanan dari aktivitas bisnis, maka komunikasi yang baik harus senantiasa dilakukan. Dalam alquran dikatakan: (43). Pergilah kamu berdua kepada Fir'aun, Sesungguhnya dia telah melampaui batas; (44). Maka berbicaralah kamu berdua kepadanya dengan kata-kata yang lemah lembut, mudah-mudahan ia ingat atau takut".

Bahkan pada musuh sekalipun, berkomunikasi menyampaikan sesuatu itu harus dengan kata-kata yang baik. Dalam hal bisnis, tidak saja kepada para pelanggan dan mitra bisnis, tetapi pada para pesaing bisnis kita misalnya, tetap harus melangsungkan prinsip public relations ini dengan sebenar-benarnya. 
Dalam sejarah, Muhammad (Rasulullah) pernah menjalankan transaksi, dengan seorang pembeli bernama Abdullah. Mereka bersepakat untuk bertemu di satu tempat untuk melaksanakan transaksi karena saat itu Muhammad membawa barang dagangan sedangkan Abdullah tidak membawa uangnya. Ternyata Abdullah lupa untuk bertemu dan teringat setelah tiga hari. Kemudian Abdullah datang ke tempat itu dan menemukan Muhammad masih menunggu dengan barang yang akan dijual. Lantas Nabi mengatakan "Engkau telah membuat aku gelisah, tiga hari aku menunggumu di tempat ini," (HR. Abu Daud). Hal ini memperlihatkan bahwa Muhammad adalah seorang yang selalu bertanggung jawab atas segala transaksi yang dilakukan. Pemikiran tentang loyality of marketing sudah ada pada dirinya yang ditunjukkan dengan pemberian layanan melebihi ekspektasi pelanggan. Hadits tersebut juga mengisyaratkan teguhnya seseorang dalam memegang ungkapan yang dikatakan kepada orang lain dalam rangka mempertahankan kelangsungan hidup bisnis yang dijalankan. Di samping Muhammad saw tahu benar bagaimana stakeholders merasa puas sehingga melahirkan re-buying dan berimplikasi pada profit yang diterima. Sosok Muhammad Saw, yang memiliki kepiawaian dalam melakukan transaksi perdagangan, telah dilatih sejak beliau berusia 12 tahun dalam melakukan perjalanan pertama kali ke Syiria bersama pamannya Abu Thalib. Begitu ilmu perniagaan diperoleh dari sang paman (Abu Thalib) dan sukses diterapkan oleh Muhammad menjadi seorang yang profesional dalam perniagaan, banyak para masyarakat yang memiliki modal namun tidak dapat melakukan perniagaannya, menginvestasikan kepada Muhammad agar dijalankan dengan penghitungan profit tertentu sebagai mitra kerja. Kecakapan Muhammad Saw. dalam melakukan perniagaan telah mendatangkan keuntungan besar bagi Khadijah dan mitra-mitra usahanya yang tersebar di seluruh Jazirah Arab. Dua puluh tahun lamanya Muhammad saw berkiprah dan malang melintang di dunia bisnis sehingga beliau dikenal sebagai seorang entrepreuner yang tangguh di Yaman, Syria, Bashra, Yordania dan kota-kota lainnya yang ada di Jazirah Arab. ${ }^{16}$

Kecenderungan masyarakat dalam dunia bisnis menginginkan profit maksimal tanpa melihat banyak bagaimana nilai-nilai normatif transenden diajarkan dalam aktivitas perekonomian. Pola hidup yang berkembang di masyarakat adalah hub al-dunya (cinta dunia), al-takatsur (berfoya-foya), konsumerisme, hedonisme yang menggiring masyarakat memisahkan nilai-nilai normatif yang bersifat ilahiyat (tauhid) dan insaniyyat (humanity). Di samping itu hal menarik saat ini adalah munculnya berbagai rumah ibadah, menjamurnya majlis ta'lim, majlis dzikir, meningkatnya masyarakat yang melakukan ibadah haji, namun di sisi lain terjadinya kemerosotan solidaritas sosial, rendahnya tertib hukum, miskin empati dan keperpihakan pada kaum dhuafa', serta menjamurnya model paham hedonisme yang berimplikasi perilaku ekonomi masyarakat.

16 Admin, Teladan rasul dalam Bisnis Masa Kini, dalam http://www.uinmalang.ac.id/index.php?option $=$ com content $\&$ view=article\&id $=377$ :teladan\&catid=27: gemaedisi-37\&Itemid=182, di unduh pada tanggal 18 feb 2013 
Implikasi paham di atas adalah sebagaimana realitas, bahwa dalam dunia bisnis timbul gejala menghalalkan segala cara demi mencapai tujuan untuk sebuah kenikmatan. Etika bersaing dalam bisnis tidak lagi tampil secara elegan, profesional dan sportif, namun cara dan budaya menerabas justru semakin tumbuh subur di tengah masyarakat. Fenomena yang timbul adalah masyarakat menempatkan agama sebagai wilayah pribadi terpisah dengan tanggung jawab sosial.

Keberhasilan Muhammad sebagai seorang entrepreneur yang tangguh dan dikenal di Jazirah Arab dan kota lainnya, tidaklah bisa terlepas dari empat sifat yang melekat dalam dirinya dan komitmen beliau menjunjung tinggi nilai-nilai luhur etika dalam bisnis. Sifat mulia yang mengantarkan kesuksesan Muhammad adalah siddiq (integrity), amanah (trust), tabligh (openly, human relation), dan fathonah (working smart). Sifat-sifat itulah yang kemudian menjadikan beliau digelari sebagai al Amin, yang berimplikasi pada munculnya berbagai pinjaman komersial (commercial loans) di kota Mekkah dan sekitarnya yang membuka peluang kemitraan antara Muhammad SAW dan para pemilik modal (funds provider).

\section{Prinsip-Prinsip Berinteraksi dengan Akhlak Islami}

Pertama, Shidq (Kejujuran). Di antara makna jujur adalah hendaknya seorang pengusaha tidak mempromosikan dagangannya dengan propaganda yang dusta dan sumpah bohong, atau memberikan penjelasan yang tidak sesuai dengan keadaan barang yang dijual untuk mengelabui pembeli, sebagaimana yang kita lihat pada era sekarang ini. Iklan dan promosi suatu produk atau barang tidak sesuai dengan barang yang di jual. Islam telah melarang perbuatan seperti ini, yang menggoyang kestabilan pasar, menghilangkan kepercayaan dan ketenangan dalam jiwa. Sesungguhnya jika seseorang melariskan barang dagangannya dengan sumpah, meskipun ia jujur (benar), Allah SWT telah menganggapnya mempermainkan sumpahnya. Karena dalam hal ini, ia telah melakukan suatu kesalahan. Sebab dunia jauh lebih hina di banding harus melariskan dagangannya dengan menyebut nama Allah(sumpah). Sesungguhnya pengusaha yang menjual dagangan mereka dengan menyebut nama Allah, dan tidak berusaha meninggalkan sumpah palsu dalam mempromosikan barangnya, akan selalu menggunakan senjata sumpah dalam setiap transaksi jual belinya. Maka ia akan mendapatkan balasan dosa yang besar, Allah tidak akan melihat pada hari kiamat nanti, dan ia tidak akan memperoleh rahmat dari-Nya. Sesungguhnya berdusta untuk mempromosikan barang dagangan dengan bersumpah atas nama Allah sebagai bentuk propaganda atau menutupi aib (cacat), ini semua membuat seorang pengusaha keluar dari wilayah kejujuran dan masuk ke dalam sikap khianat. Allah akan menghapus keberkahan dalam jual belinya akibat perbuatannnya. Hendaknya seorang pengusaha menjaga mitra-mitra bisnisnya, mencintai mereka sebagaimana ia mencintai diri sendiri. Hendaknya ia menjelaskan secara gamblang kepada mereka apa yang berkaitan dengan mu'amalah secara fair, dan tidak egois dalam perhitungan harta (hasil usaha) mereka. 
Kedua, amanah. Sesungguhnya menutupi aib dan promosi yang berlebihan terhadap barang yang dijual tidak akan menambah rezeki. Bahkan hal tersebut dapat menghapus dan menghilangkan keberkahannya. Harta tidaklah akan bertambah dengan berkhianat. Sebagaimana ia juga tidak berkurang dengan bersedekah. Satu dirham yang diberkahi oleh Allah yang menjadikan sebab kebahagiaan manusia di dunia dan di akhirat jauh lebih baik dari pada berjuta-juta dirham yang dapat menghapus keberkahan, yang terkadang justru menjadikan sebab kehancuran bagi pemiliknys dan menimbulkan kerugian didunia dan agama.

Ketiga, toleransi. Di antara makna toleransi adalah hendaknya seorang pengusaha menjaga hak-hak mitra bisnisnya, tidak menjadikan harta sebagai penyebab ketamakan dan kerakusan atas hak-hak orang lain, terlebih setelah usahanya sukses. Hendaknya tidak bangga dengan kebaikan diri sendiri, sebab sekiranya bukan berkat taufik Allah kepadanya dan harta para mitra usahanya, tidaklah akan tumbuh dan berkembang usahanya. Dan jika berbicara tentang likuidasi dan pemutusan (hubungan kerja), maka hendaklah ia melakukannya dengan ma'ruf (baik).

Keempat, tepati Janji. Dalam Islam ada beberapa cara yang digunakan untuk menguatkan janji atau transaksi mu'amalah, diantaranya: a). Kitabah (pencatatan), b). Syahadah (kesaksian), c). Jaminan, baik berupa orang atau barang. Maka sangat diperlukan bagi seorang pengusaha untuk konsisten dengan ajaran dan norma ini agar dapat mengatasi segala problem dalam muamalah mereka. Sehingga ketika datang waktu perhitungan antara mereka tidak ada prasangka buruk. Dengan adanya kesepakatan (perjanjian) ini semua masalah akan beres dan kedua belah pihak dapat saling merelakan.

\section{Penutup}

Konsep public relations pada dekade ini telah mengalami perkembangan yang cukup signifikan. Digitalisasi informasi dan derasnya laju informasi membuat Konsep public relation harus kembali dikaji. Konsep public relation berkembang dan pada perjalanannya memasukan konsep dan strategi digital dalam lingkup kerjanya.

Definisi yang paling terbaru dan populer berbunyi: Public relations adalah sebuah proses komunikasi strategis yang membangun hubungan saling menguntungkan antara organisasi dan publik mereka. Definisi tersebut akan digunakan sebagai sandaran praktek PR di masa mendatang. Sifatnya tidaklah statis. Ini dapat terus berubah seiring perkembangan yang ada, karenanya hanya akan digunakan sebagai sandaran. Terkait fungsi dan tugas serta peran public relations, seluruhnya mengarahkan pada keterikatan dan keterkaitan posisinya di organisasi/perusahaan dengan lingkungannya, baik itu pelanggan, stakeholders, masyarakat maupun dengan internal perusahaan itu sendiri.

Dalam kontek bisnis Islami, public relations merupakan alat komunikasi yang efektif, luas serta sistematis sehingga menjadi bagian yang terintegrasi baik secara langsung maupun tidak langsung dalam diri entrepreneur muslim dalam menjalankan seluruh aktivitas bisnisnya. Ini tergambar dalam diri seorang Muhammmad Al-Amiin. 


\section{Pustaka Acuan}

Andini Marta, Manajemen dan Public Relations, dalam http://strategikomunikasi. blogspot.com/2012/02/ manajemen-dan-public-relations.html, diunduh pada tanggal 6 feb 2013

Ani Yuningsih, Peran Sstrategis Profesi Public Relation Dalam Membangun Kemintraan Berbasis Nilai Spiritual; Studi Deskriptif Analitis terhadap Peran Strategis Profesi PublicRelations Sebagai Fasilitator Kemitraan Antara Pemerintah, Komunitas Sipil dan Komunitas Bisnis dalam Meningkatkan Indeks Pembangunan Manusia (IPM) di Jawa Barat, Jurnal Mimbar, Volume XXII No. 4 Oktober - Desember 2006

F. Rachmad, Public Relations dalam Teori dan Praktek, (Jakarta, Pt. Gramedia Pustaka Utama, 1993, hal 111. Lihat juga Redi Panuju, Komunikasi Bisnis, (Jakarta, PT. Gramedia Pustaka Utama, 2000), Cet-ke 2.

Irmulan Sati, Manajemen Public Relations, dalam http://kk.mercubuana.ac.id/files/99006-3-549085894829.doc, di unduh pada tanggal 8 februari 2013.

Lucy Indrawati, Analisis Strategi Internal Public Relations Dalam Mengembangkan Komunikasi Dengan Pihak Investor (Studi Kasus Pada PT Barito Pasivic Tbk) dalam http://library.binus.ac.id/eColls/eThesis/Bab2/2011-2-00638MC\%20Bab2001.pdf, diunduh pada tanggal 18 Februari 2013.

Mike Beard, Manajemen Departemen Public Relations, (Jakarta: Penerbit Erlangga, 2001), Edisi Kedua.

Patricia J. Parson, Etika Public Relations; Panduan Praktik Terbaik (terj), (Jakarta:Esesnsi Erlangga Group, 2006).

Redi Panuju, Komunikasi Bisnis, (Jakarta, PT. Gramedia Pustaka Utama, 2000), Cetke 2.

Rosady Ruslan, Metode Penelitian Public Relations dan Komunikasi, (jakarta: PT RajaGrafindo Persada, 2003).

S.K. Bonar, Hubungan Masyarakat Modern, (Jakarta : penerbit Rineka Cipta, 1993), Cetakan -3 .

Sutrisna Dewi, Komunikasi Bisnis, (Yogyakarta, Penerbit : ANDI Yogyakarta, 2007).

Admin, Public Relations dan Komunikasi Publik, dalam http://www.duniaesai.com/index.php?option=com content\&view=article\&id $=470$ :pr-dan-komunikasi-publik\&catid=41:komunikasi\&Itemid=93 diunduh pada tanggal 18 Februari 2013

Admin, Tantangan dan Kompetensi Profesi Public Relations, dalam http://operadewa.wordpress.com/2011/12/11/tantangan-dan-kompetensiprofesi-public-relations/, di undunh pada tanggal 18 Februari 2013

Admin, Teladan rasul dalam Bisnis Masa Kini, dalam http://www.uinmalang.ac.id/index.php?option=com content\&view=article\&id $=377$ :teladan \&catid=27:gema-edisi-37\&Itemid=182, di unduh pada tanggal 18 feb 2013. 